\title{
Konsep Kepemimpinan dan Pelaksanaan Supervisi Akademik Kepala Sekolah dalam Sistem Pendidikan Muhammadiyah (Studi Kasus SMP Muhammadiyah 1 Medan)
}

\author{
Aulia \\ Mahasiswa Pasca Sarjana UIN SU \\ (Email: auliadaiamcf9@gmail.com)
}

\begin{abstract}
ABSTRAK
Penelitian ini bertujuan untuk: mengetahui konsep kepemimpinan dan pelaksanaan supervisi akademik kepala sekolah, serta sistem pendidikan di SMP 1 Muhammadiyah Medan. Jenis penelitian adalah penelitian kualitatif dengan pendekatan studi kasus. Data dikumpulkan dengan metode wawancara dan observasi. Agar data tersebut dapat dipercaya (valid), maka dilakukan pengujian keabsahan data. Langkah terakhir adalah melakukan analisis data, dengan tiga cara: (1) mereduksi data, dengan membuang data yang tidak diperlukan (2) menyajikan data yang sesuai dengan dan menghubungkan antara data yang satu dengan lainnya, sehingga memberikan informasi yang utuh pada permasalahan yang dibicarakan (3) menginterpretasi data tersebut menganalisisnya, dan menyimpulkannya. Berdasarkan hasil pembahasan diperoleh informasi bahwa, konsep kepemimpinan yang dilakukan oleh kepala sekolah adalah dengan memajukan sekolah secara internal dan eksternal, menjalin komunikasi yang baik dengan guru atau pegawai, menanggapi kesulitan yang dihadapi oleh guru dengan melimpahkan kepada ahlinya, menasehati guru atau pegawai yang melanggar peraturan, memberikan penghargaan kepada guru atau pegawai yang berprestasi, mengadakan dan melibatkan guru dan pegawai ketika rapat, menjadi penentu keputusan, menyampaikan visi, misi dan tujuan sekolah, meningkatkan kemampuan manajerialnya melalui informasi dan pelatihan, memberdayakan penggunaan fasilitas sekolah, menanamkan akhlak al-karimah di sekolah, memberikan motivasi dan meningkatkan kinerja guru, merekrut dan menempatkan guru atau pegawai berdasarkan profesionalitas dan akhlaknya, mengevaluasi kinerja pegawai, khususnya guru, serta yang terakhir ikut berkontribusi terhadap pencapaian prestasi siswa. Adapun pelaksanaan supervisi akademik oleh kepala sekolah dapat dilihat dari nilai PKG sebagian guru yaitu, sudah berada pada level amat baik, begitu juga dengan nilai rata-rata keseluruhan guru, sedangkan yang terendah hanya dua orang saja yang berpredikat baik. Kepemimpinan kepala sekolah dalam sistem pendidikan berada di bawah pengawasan dan bertanggung jawab kepada suatu lembaga yang disebut Dikdasmen.
\end{abstract}

Key Word: Konsep Kepemimpinan, Pelaksanaan Supervisi Akademik, Sistem Pendidikan Muhammadiyah 


\section{A. PENDAHULUAN \\ 1.1. Latar Belakang Masalah}

Kepemimpinan merupakan titik sentral dari suatu organisasi, keberhasilan suatu organisasi akan tergantung pada kemampuan pemimpinnya dalam menggerakkan segala sumber daya dan dana yang ada dalam organisasi itu. ${ }^{1}$ Berdasarkan pernyataan di atas, dapat dikatakan bahwa, kepemimpinan memiliki hubungan yang erat dengan organisasi. Salah satu contoh organisasi adalah sekolah, seperti yang diungkapkan oleh Hoy dan Miskel, "sekolah merupakan organisasi pelayanan yang berkomitmen pada pengajaran dan pembelajaran. Sekolah, berbeda dengan jenis organisasi lainnya, harus menjadi organisasi pembelajaran (learning organization).,"2

Apabila digabungkan dua pernyataan di atas, dapat disimpulkan bahwa keberhasilan organisasi yaitu sekolah tergantung pada kemampuan pemimpinnya, atau kepemimpinan

\footnotetext{
${ }^{1}$ Veithzal Rivai dan Sylviana Murni, Education Management: Analisis Teori dan Praktik (Jakarta: Rajawali Pers, Edisi I, cetakan ke-2, 2010), h. 284

${ }^{2}$ Wayne K. Hoy dan Cecil G. Miskel, Administration : Theory, Research and Practice dalam Saiful Bahri, Optimalisasi Kinerja Kepala Sekolah (Jakarta : Gibon Books, 2010), h. 21
}

kepala sekolahnya. Adapun mengenai pentingnya supervisi akademik bagi kemajuan sekolah dapat dilihat dari penjelasan Eny sebagai berikut:

Kegunaan supervisi adalah untuk meningkatkan kemampuan profesional guru dalam meningkatkan kemampuan profesional guru dalam meningkatkan proses hasil belajar melalui pemberian bantuan yang terutama bercorak layanan profesional kepada guru. Jika proses belajar meningkat, maka hasil belajar diharapkan juga meningkat. Dengan demikian, rangkaian usaha supervisi profesional guru akan memperlancar pencapaian tujuan kegiatan belajar mengajar. Diharapkan mutu pendidikan sekolah secara kontinyu mengalami peningkatan. $^{3}$

Keberhasilan suatu sekolah yang dikelola oleh kepala sekolahnya ditandai dengan pencapaian prestasi oleh para siswa, sebagaimana yang diutarakan oleh Mukhtar:

Kepala sekolah merupakan orang yang paling penting di suatu sekolah. Kepala sekolah merupakan kunci bagi

\footnotetext{
3 Eny Winaryati, Evaluasi Supervisi Pembelajaran: Dilengkapi Instrumen Pembelajaran (Yogyakarta: Graha Ilmu, cetakan ke-1, 2014), h. 5
} 
pengembangan dan peningkatan suatu sekolah. Indikator dari keberhasilan sekolah adalah apabila sekolah tersebut berfungsi dengan baik, terutama apabila prestasi-prestasi murid dapat dicapai secara maksimal. ${ }^{4}$

SMP Muhammadiyah 1 Medan merupakan sekolah yang memiliki banyak prestasi, baik di bidang akademik maupun di bidang ekstrakurikuler. Data terbaru yang diperoleh melalui hasil wawancara dengan kepala sekolah SMP Muhammadiyah 1 Medan, beliau mengatakan, pada tahun 2015, SMP Muhammadiyah meraih juara III olimpiade matematika tingkat internasional.

Mengingat begitu pentingnya peranan kepemimpinan dan pengawasan, terutama pengawasan pengajaran guru yang dilakukan oleh kepala sekolah bagi kemajuan suatu sekolah, dan adanya pengaruh kepala sekolah bagi keberhasilan sekolah yang ditunjukkan dengan prestasi yang diperoleh para siswanya, serta adanya sekolah yang memiliki banyak prestasi seperti SMP Muhammadiyah 1 Medan, maka penulis tertarik untuk melakukan penelitian

4 Mukhtar, et.al, Sekolah Berprestasi (Jakarta: Nimas Multimah, cetakan ke-3, 2005), h. 54 dengan judul, Konsep Kepemimpinan dan Pelaksanaan Supervisi Akademik Kepala Sekolah dalam Sistem Pendidikan Muhammadiyah (Studi Kasus SMP Muhammadiyah 1 Medan).

\subsection{Rumusan Masalah}

Masalah di atas dapat dirumuskan sebagai berikut:

1. Bagaimana konsep kepemimpinan kepala sekolah SMP Muhammadiyah 1 Medan?

2. Bagaimana pelaksanaan supervisi akademik kepala sekolah di SMP Muhammadiyah 1 Medan?

3. Bagaimana sistem pendidikan Muhammadiyah di SMP Muhammadiyah 1 Medan?

\subsection{Batasan Istilah}

Pada latar belakang masalah disebutkan bahwa kepala sekolah memiliki banyak peranan terhadap sekolah, namun pada penelitian ini penulis membatasinya hanya pada peranan kepemimpinan dan supervisinya saja. Demikian juga, supervisi juga terbagi kepada supervisi administratif dan supervisi akademik, namun pada penelitian ini penulis membatasinya 
pada supervisi akademik saja. Pengelolaan sekolah dilakukan oleh

Majelis Pendidikan dasar dan menengah

(Dikdasmen) cabang Muhammadiyah dan

kepala sekolah, namun pada penelitian ini penulis hanya mengkaji dari sudut pandang

kepala sekolahnya saja.

\subsection{Tujuan Penelitian}

1. Untuk mengetahui bagaimana konsep kepemimpinan kepala sekolah di SMP Muhammadiyah 1 Medan

2. Untuk mengetahui bagaimana pelaksanaan supervisi akademik kepala sekolah di SMP Muhammadiyah 1 Medan

3. Untuk mengetahui bagaimana sistem pendidikan Muhammadiyah di SMP Muhammadiyah 1 Medan

\subsection{Kegunaan Penelitian}

Secara teoritis, penelitian ini dapat dimanfaatkan sebagai bahan pertimbangan dan tambahan informasi bagi peneliti yang ingin melakukan suatu penelitian yang ada kaitannya dengan judul penelitian ini

Secara praktis, penelitian ini dapat dipergunakan sebagai bahan masukan bagi pihak sekolah bagi perbaikan dan kemajuan sekolah di masa yang akan datang.

\section{B. KAJIAN PUSTAKA}

\subsection{Pengertian Kepemimpinan Kepala} Sekolah

Menurut Kamus Besar Bahasa Indonesia, secara etimologi kepemimpinan berasal dari kata pimpin: dalam keadaan dibimbing, dituntun, sedangkan kepemimpinan: perihal memimpin, cara memimpin. ${ }^{5}$

Terdapat banyak pengertian tentang kepemimpinan yang dikemukakan oleh para ahli manajemen, tapi dalam penelitian ini, penulis hanya memaparkan beberapa pengertian saja sebagai berikut:

Bennis dan O'Toole berpendapat,"the art or process of influencing people so that they will strive willingly and enthusiastically toward the achievement of group goals."6

[Kepemimpinan didefinisikan sebagai pengaruh, yaitu, seni atau proses mempengaruhi orang sehingga mereka akan rela bekerja keras dan penuh semangat

5 Pusat Bahasa Departemen Pendidikan Nasional, Kamus Besar Bahasa Indonesia,(Jakarta: Balai Pustaka,Edisi III, cetakan ke-4, 2007), h. 874

${ }^{6}$ Warren Bennis dan James O'Toole, Don't Hire the Wrong CEO(article) dalam Heinz Weihrich dan Harold Koontz, Management: a Global Perspective (Singapore: The McGraw-Hill Companies, Edisi XI, 2005), h. 396 
menuju pencapaian tujuan-tujuan hubungan-hubungan dalam suatu kelompok]

kelompok atau organisasi]

Terry menjelaskan bahwa," Sesuai dengan konteks pembahasan, yaitu leadership is the relationship in which one mengenai kepemimpinan kepala sekolah, person, the leader, influence other to work penulis mengutip pernyataan Bernbaum, together willingly on related tasks to attain sebagai berikut: "Headteachers as that which the leader desires."7

[Kepemimpinan adalah hubungan school leaders were expected to have a mission to bring the school and its members di mana seseorang, pemimpin, nearer to the great pedagogic ideal of the mempengaruhi orang lain agar rela bekerja sama atas tugas-tugas terkait untuk memperoleh sesuai dengan keinginankeinginan pemimpin]

Yukl menyimpulkan,"most definitions of leadership reflect the assumption that it involves a process whereby intentional influence is exerted over other people to guide, structure, and facilitate activities and relationships in a group or organization." $"$

[Kebanyakan definisi tentang kepemimpinan mencerminkan anggapan bahwa dia (kepemimpinan) melibatkan proses di mana pengaruh yang sengaja digunakan atas orang lain untuk membimbing, menyusun, dan memfasilitasi kegiatan-kegiatan dan

7 George R. Terry, Principles of Management (Illinois: Richard D.Irwin Inc, Edisi VII, 1977), h. 410-411

${ }^{8}$ Gary Yukl, Leadership in Organizations (New York: Pearson Prentice Hall, Edisi VII, 2010 ), h. 21

time, that of 'godliness and good learning'.

This was the essence of educational leadership and it applied to all schools."9

[Para kepala sekolah sebagai para pemimpin sekolah diharapkan memiliki misi untuk membawa sekolah dan para anggotanya lebih dekat ke pedagogik (seni mendidik) yang hebat, waktu yang ideal, yaitu dari kesalehan dan belajar yang baik. Ini adalah hakikat dari kepemimpinan pendidikan dan diterapkan untuk semua sekolah]

Berdasarkan uraian di atas dapat disimpulkan bahwa, kepemimpinan kepala sekolah menurut para ahli adalah seni atau proses dari orang-orang yang memiliki kemampuan dalam mempengaruhi orang lain agar orang lain yang dipimpin tersebut

${ }^{9}$ G. Bernbaum, The Role of the Head dalam Gerald Grace, School Leadership: Beyond Education Management An Essay in Policy Scholarship (London: The Falmer Press, 1995), h. 30 
rela bekerja keras dan penuh semangat dengan menyusun, membimbing dan memfasilitasi kegiatan-kegiatan atau hubungan-hubungan orang lain yang dipimpin tersebut untuk mendukung aktivitas-aktivitas dan program-program pengajaran agar tercipta keadaa paedagogis yang baik di sekolah.

\subsection{Konsep Kepemimpinan Kepala} Sekolah

Ametembun membagi konsep kepemimpinan terdiri atas: konsep traits, konsep situasional, dan konsep general. ${ }^{10}$

\subsubsection{Konsep Traits}

Yukl mendefinisikan konsep traits, "The term traitrefers to a variety of individual attributes such as: personality, temperament, needs, motives, and values. Personality traits are relatively constant dispositions to behave in a specific way. For instance include self-confidence, extroversion, emotional maturity, and energy level." $" 11$

[Istilah traits merujuk berbagai sifat individu, termasuk aspek-aspek

${ }^{10}$ N.A.Ametembun, Kepemimpinan dalam Perubahan Pendidikan: Suatu Pendekatan Sistem (Bandung:IKIPBandung, cetakan ke-2, 1981), h. 2840

\footnotetext{
${ }^{11}$ Yukl, Leaderdhip, h. 43
}

kepribadian, temperamen, kebutuhan, niat, dan martabat. Sifat-sifat kepribadian cenderung tidak berubah untuk berperilaku dengan cara tertentu. Contohnya termasuk kepercayaan diri, senang bergaul, kematangan emosional, dan tingkat kekuatan]

\subsubsection{Konsep Situasional}

Konsep situasional yang populer oleh Hersey dkk, berbunyi, “ no one style is effective in all situations. Each style is appropriate and effective depending on the situation." 12

[Tidak ada satu gaya yang efektif dalam semua situasi. Setiap gaya yang tepat dan efektif tergantung pada situasi]

Lebih lanjut mereka menjelaskan sebagai berikut :

a. If the staff member is inexperienced and insecure about performing in a particular area, a telling style would be appropriate for the manager to use. If this is the case, they should schedule frequent meetings so that the manager can work closely with the staff member.

b. If the staff member is willing but inexperienced in a particular area, the manager should utilize a selling style. This would involve scheduling meetings to work with the staff member, but not as frequently as under (S1) supervision.

\footnotetext{
${ }^{12}$ Paul Hersey et.al., Management of Organizational Behavior: Leading Human Resources (India: Prentice Hall of India Private Limited, Edisi ke-8, 2002), h. 174
} 
c. If the staff member is able in a particular area but is a little insecure about working completely alone, a participating leadership style would be appropriate. That may involve meeting periodically over lunch so that the staff member can show the manager what has been accompished and the proper support and encouragement can be given.

d. If the staff member is able and willing to perform at desired level in a particular objective area, no meetings are necessary unless called by the staff member. In this case, performance review can occur on an frequent basis. ${ }^{13}$

a. [Jika anggota staf berpengalaman dan tidak aman tampil di daerah tertentu, gaya pemberitahuan cocok digunakan manajer. Jika kasus ini yang terjadi, mereka harus menjadwalkan banyak pertemuan sehingga manajer dapat bekerja lebih dekat dengan anggota staf.

b. Jika anggota staf bersedia tapi tidak berpengalaman di daerah tertentu, manajer sebaiknya menggunakan gaya menjual. Hal ini akan melibatkan jadwal rapat-rapat agar dapat bekerja dengan anggota staf, tapi tidak seseringgaya yang pertama

c. Jika anggota staf mampu di daerah tertentu, tetapi sedikit tidak aman bekerja benar-benar sendirian, gaya kepemimpinan yang berpartisipasi akan sesuai. Yang mungkin melibatkan pertemuan berkala pada saat makan siang sehingga anggota staf dapat menunjukkan kepada manajer apa yang telah dicapai, dan dukungan dan doronganyang tepat dapat diberikan.

d. Jika anggota staf mampu dan bersedia untuk tampil di tingkat yang diinginkan di daerah tujuan tertentu, tidak diperlukan pertemuan kecuali dipanggil

\footnotetext{
${ }^{13}$ Ibid, h. 292
}

oleh anggota staf. Dalam hal ini, tinjauan kinerja(evaluasi) dapat sering dilakukan]

\subsubsection{Konsep General}

Menurut Purwanto, konsep general ini memandang kepemimpinan sebagai fungsi kelompok (function of the group). Konsep ini tidak lagi menekankan pada kemampuan atau sifat seorang pemimpin semata, tetapi lebih dari itu, yang menentukan kepemimpinan adalah sifat dan karakteristik sekelompok orang yang dipimpin oleh pemimpin tersebut. Setiap kelompok mempunyai keunikan sifat dan karakteristik tersendiri sehingga harus diperlakukan dengan tipe atau gaya kepemimpinan yang berbeda-beda... ${ }^{14}$

\subsection{Supervisi Akademik Kepala Sekolah}

\subsubsection{Pengertian Supervisi Akademik Kepala Sekolah}

Penulis mengemukakan beberapa pengertian mengenai supervisi akademik dengan mengutip pendapat para ahli sebagai berikut :

Wiles menyatakan bahwa, ..."Supervision is a service activity that exists to help teachers do their job better. ${ }^{15}$

[Supervisi adalah sebuah usaha pelayanan yang muncul untuk menolong

14 Ngalim Purwanto, Administrasi dan Supervisi Pendidikan (Bandung: Remaja Rosda Karya, cetakan ke-15, 2005), h. 24-25

15 Kimball Wiles, Supervision for Better School (Englewood Cliffs, New Jersey: PrenticeHall Inc, Edisi III, 1967),h.5 
para guru melakukan pekerjaan mereka menjadi lebih baik]

Arikunto menjelaskan, "supervisi akademik adalah supervisi menitikberatkan pengamatan pada masalah akademik, yaitu yang langsung berada dalam lingkup kegiatan pembelajaran yang dilakukan oleh guru untuk membantu siswa ketika sedang dalam proses belajar."16

Kemudian beliau memberikan contoh, sebagai misal, kepala sekolah yang lebih dekat dengan sekolah bahkan justru melekat pada kehidupan sekolah yang lebih banyak mengarahkan perhatiannya pada supervisi akademik, sedang pengawas yang relatif lebih jarang datang ke sekolah karena jumlah sekolah yang menjadi pembinaannya cukup banyak, mengarahkan perhatiannya pada supervisi administrasi. $^{17}$

\subsubsection{Pelaksanaan Supervisi Akademik Kepala Sekolah}

Aseltine dan Judith membagi tahapan supervisi kepada enam tahapan:

a. Teacher Preparation. This is the process by which the teacher starts to collect evidence about student learning necessaries and to develop an emerging idea for a clear, narrow, and standardsbased area of important extremely learning as an appropriate focus for an improvement objective.

b. Initial Collaboration. The teacher and supervisor analyze student data more deeply and finalize the focus and details

16 Suharsimi Arikunto, Dasar-Dasar Supervisi (Jakarta: Rineka Cipta, cetakan ke-1, 2004), h. 5

${ }^{17}$ Ibid, h. 7 of the improvement objective and the professional development plan.

c. Initial Monitoring. The teacher begins to participate in professional development and to implement strategies that support student learning, making necessary adjustments as the process unfolds.

d. Mid-Cycle Review. At half of year, or another appropriate midpoint, the teacher and supervisor review progress to date, checking artifacts connected to teacher initiatives and, furthermore, student work, and modifying the plan as needed.

e. Secondary Monitoring. The teacher continues to carry out the professional development plan and deepens learning related to student needs by using more refined assessment methods to inform instructional decisions.

f. Summative Review. At the final of each cycle, the teacher and supervisor review hint linking teaching strategies to student learning results, and develop written reflections that detail teacher growth and suggest ideas for further development in the next cycle. $^{18}$

a. [Persiapan guru. Ini adalah proses di mana guru mulai mengumpulkan informasi tentang kebutuhan belajar siswa dan mengembangkan ide yang muncul untuk daerah yangberdasarkan standar-standar yang jelas, sempit, dari pembelajaran yang penting sebagai sasaran yang tepat untuk suatu tujuan perbaikan.

\footnotetext{
${ }^{18}$ James M. Aseltine. et.al, Supervision for Learning: a Performance Based Approach to Teacher Development and School Improvement (Virginia: Association for Supervision and Development, 2006), h. 15-16
} 
b. Kolaborasi awal. Guru dan supervisor menganalisis data siswa lebih dalam dan menyelesaikan fokus dan detail dari tujuan perbaikan dan rencana pengembangan profesional.

c. Pemantauan awal. guru mulai berpartisipasi dalam pengembangan profesi dan menerapkan strategi-strategi yang mendukung pembelajaran siswa, membuat penyesuaian yang diperlukan sebagai proses pengembangan

d. Tinjauan siklus pertengahan. Pada pertengahan tahun, atau pertengahan (waktu) lain yang sesuai, guru dan supervisor meninjau kemajuan sampai saat ini, memeriksa bahan-bahan (informasi) yang terkait dengan inisiatif guru dan, jika mungkin, pekerjaan siswa, dan mengubah (bentuk) rencana yang diperlukan.

e. Pemantauan sekunder. Guru terus melaksanakan rencana pengembangan profesional dan memperdalam pembelajaran yang terkait dengan kebutuhan siswa dengan menggunakan metode-metode penilaian yang lebih halus untuk memberitahukan keputusan pengajaran.

f. Tinjauan sumatif. Pada akhir setiap siklus, guru dan supervisor meninjau bukti (petunjuk) yang menghubungkan strategi-strategi pengajaran terhadap hasil belajar siswa, dan mengembangkan gambaran tertulis yang menjelaskan pertumbuhan guru dan menyarankan ide-ide untuk pengembangan lebih lanjut dalam siklus berikutnya].

\subsection{Sistem Pendidikan Muhammadiyah}

Siddik memberikan gambaran terperinci mengenai latar belakang pendidikan Muhammadiyah yaitu, Ahmad Dahlan sangat prihatin terhadap kondisi

pendidikan umat Islam pada masa itu, baik di pesantren maupun di sekolahsekolah gubernemen. Dalam pengamatannya, pendidikan di pondokpondok pesantren pada masa itu, selain metodologi pengajarannya yang kurang efektif, juga kurang membekali santrinya dalam bidang ilmu pengetahuan yang dapat digunakan untuk memecahkan persoalan-persoalan duniawi. Sedangkan di sekolah-sekolah gubernemen yang secara metodik dan teknik penyelenggaraannya lebih modern, tetapi karena isi pelajarannya sama sekali tidak bersentuhan dengan iman dan kesalehan sebagai tujuan fundamental pendidikan Islam, menyebabkan sekolah ini pun sama sekali tidak dapat diharapkan menjadi alternatif bagi pendidikan umat Islam. ${ }^{19}$

Lubis mengatakan, ada dua upaya

KH. Ahmad Dahlan menyikapi hal tersebut, yaitu memasukkan pelajaran agama ke dalam lembaga pendidikan barat dan penetrapan (sic) sistem pendidikan barat dalam lembaga pendidikan agama. ${ }^{20}$

a. Pemikiran yang pertama ini tertuang dalam keputusan rapat Muhammadiyah pada bulan April 1992 yang memutuskan, bahwa Muhammadiyah meminta pada pemerintah supaya memberikan keizinan

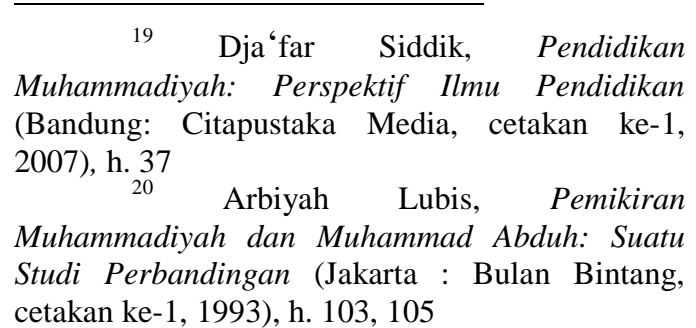


pada orang Islam mengajarkan agama Islam dalam sekolah-sekolah Gobernemen. $^{21}$

Nasution mengatakan, sebelum permohonan tersebut dimasukkan dalam agenda rapat, Kiai Ahmad Dahlan sendiri telah merintis usaha ke arah itu, jauh sebelum Muhammadiyah didirikan. Permintaan pemberian izin tersebut adalah pemberian izin untuk mengajarkan mata pelajaran agama di sekolah pemerintah secara resmi, dan tentunya dengan mencabut larangan yang dikeluarkan sebelumnya. $^{22}$

b. Sistem pendidikan barat yang dimaksud di sini adalah cara yang diterapkan di lembaga pendidikan kolonial dalam beberapa komponen pendidikan. Cara tersebutlah tampaknya yang diserap oleh Ahmad Dahlan khususnya dan kemudian melahirkan sistem pendidikan baru yang merupakan kompromi antara sistem pendidikan kolonial dengan sistem pendidikan Islam tradisional. Sistem pendidikan yang baru inilah tampaknya yang menjadi ciri khas sistem pendidikan Muhammadiyah. Sistem pendidikan yang demikian tercermin dalam beberapa lembaga pendidikan yang didirikan oleh Ahmad Dahlan dan kemudian menjadi lembaga pendidikan Muhammadiyah. ${ }^{23}$

Hasbullah menambahkan, ...faktor pemicu lainnya, yang menjadi pendorong Ahmad Dahlan, adalah pikiran-pikiran

\footnotetext{
${ }^{21}$ Verslag Moehammadijah di Hindia Timoer ke X dalam Lubis, Pemikiran, h. 103

${ }^{22} \mathrm{~S}$. Nasution, Sejarah Pendidikan Indonesia dalam Lubis, Pemikiran, h. 103-104

${ }^{23}$ Amir Hamzah Wiryosukarto, Pembaharuan Pendidikan dan Pengajaran Islam, dalam Lubis, Pemikiran, h.105
}

Muhammad Abduh, yang termuat dalam tulisannya seperti pada majalah Al-Manar. Majalah ini juga menjadi salah satu bacaan Ahmad Dahlan... ${ }^{24}$

\section{Metodologi Penelitian}

\subsection{Jenis dan Pendekatan Penelitian}

Penulis melakukan penelitian dengan menggunakan metode penelitian kualitatif. Dalam pendekatan kualitatif, ada beberapa pendekatan pula yang bisa dirujuk. Ada beberapa alternatif pendekatan penelitian kualitatif yang bisa dipilih oleh para peneliti sebelum melakukan penelitian. Pemilihan pendekatan tertentu tentu didasarkan atas masalah yang akan diteliti. Beberapa pendekatan yang bisa dipilih dalam penelitian kualitatif adalah studi kasus, grounded theory, etnografi dan analisis wacana. ${ }^{25}$

Adapun pendekatan yang dipergunakan oleh penulis pada penelitian ini adalah studi kasus.

\subsection{Lokasi dan Waktu Penelitian}

Lokasi penelitian dilakukan adalah SMP Muhammadiyah 1 Medan, sedangkan waktu untuk melakukan

\footnotetext{
${ }^{24}$ Djarnawi Hadikusumo, dari Jamaluddin al-Afgani sampai KH. Ahmad Dahlan, dalam Hasbullah, Kapita, h. 118

${ }^{25}$ Tohirin, Metode Penelitian Kualitatif dalam Pendidikan dan Bimbingan dan Konseling ; Pendekatan Praktis untuk Peneliti Pemula dan Dilengkapi dengan Contoh Transkrip Hasil Wawancara serta Model Penyajian Data (Jakarta: Rajawali Pers, Edisi I, cetakan ke-3, 2013), h. 19
} 
penelitian diperkirakan selama kurang lebih 2-3 bulan.

\subsection{Informan Penelitian}

Informan dalam penelitian ini adalah kepala sekolah SMP Muhammadiyah 1 Medan, wakil kepala sekolah, para guru dan pegawai di sekolah tersebut.

\subsection{Sumber Data}

sumber data diperoleh dari hasil wawancara, hasil pengamatan di lapangan dan dokumen-dokumen yang berkaitan dengan penelitian yang dapat memberikan informasi mengenai kepemimpinan kepala sekolah dan pelaksanaan supervisi kepala sekolah di SMP Muhammadiyah 1 Medan.

\subsection{Teknik Pengumpulan Data}

Untuk memperoleh informasi mengenai konsep kepemimpinan kepala sekolah, penulis menggunakan metode wawancara. Wawancara tersebut disusun dengan mempertimbangkan aspek-aspek kegiatan yang dilakukan oleh kepala sekolah dalam menjalankan kepemimpinannya di sekolah. Adapun untuk mendapatkan informasi tentang pelaksanaan supervisi akademik kepala sekolah, yaitu dengan mengamati instrumen yang sudah baku yang telah ditetapkan oleh Kemendiknas yang dipakai oleh kepala sekolah ketika melakukan supervisi di kelas yang disebut dengan PKG ( penilaian kinerja guru) yang disajikan dalam bentuk angka. Oleh karena data yang akan diperoleh melalui PKG tersebut dalam bentuk angka, maka data tersebut diolah lagi dengan skala Likert agar dapat diinterpretasikan ke dalam kata-kata. Dokumen-dokumen yang terkait dan dapat mendukung penelitian ini dapat juga dihadirkan untuk menambah informasi.

\subsection{Teknik Analisis Data}

Beberapa data yang telah diperoleh dari teknik pengumpulan data, baik berupa wawancara, observasi, studi dokumenter, dikumpulkan dan dipilih. Data-data yang sesuai dengan subjek penelitian diambil dan dipergunakan, sedangkan data yang tidak sesuai, dibuang. Setelah data-data tersebut dipilih, maka dirangkai dan digabungkan antara satu data dengan data yang lain, sehingga menjadi sebuah teks naratif deskriptifyang utuh, kemudian teks naratif deskriptif tersebut diinterpretasikan dan dianalisis oleh penulis untuk menjawab pertanyaan 
sebelumnya yang telah diajukan pada rumusan masalah.

\section{Hasil dan Pembahasan}

\subsection{Konsep Kepemimpinan Kepala} Sekolah SMP Muhammadiyh 1 Medan

Untuk memajukan sekolahnya, kepala sekolah SMP Muhammadiyah 1 Medan melakukan langkah-langkah: menegakkan disiplin, mewujudkan kebersihan serta melakukan pelatihan-pelatihan di sekolah, melakukan studi banding ke sekolah lain, mengikuti dan mengekspos even perlombaan di media, dan mengiklankan sekolah melalui spanduk-spanduk. Hubungan antara pegawai dan guru dengan kepala sekolah terjalin dengan baik. Perekrutan guru dan pegawai dilakukan oleh kepala sekolah sesuai dengan latar belakang pendidikan (mempertimbangkan profesionalitas kemampuan yang dimiliki) melalui seleksi baik dari segi akademiknya maupun keagamaannya, setelah mendapatkan izin dari Dikdasmen. Kinerja guru dievaluasi dengan PKG( penilaian kinerja guru, penilaian agenda guru, penilaian setelah ujian, untuk mengetahui program mana yang telah dilaksanakan dan mana yang belum, dan yang terakhir adalah penilaian agenda program rutin guru dan siswa. Apabila ada guru yang menghadapi kesulitan, kepala sekolah turut membantu dengan menyediakan BK dan psikolog. Apabila ada yang melanggar peraturan, maka diberikan nasehat terlebih dahulu oleh kepala sekolah sebelum diberikan surat peringatan, sedangkan kepada yang berprestasi diberikan penghargaan dan hadiah. Selain itu para guru dan pegawai juga diberi motivasi oleh kepala sekolah baik daam bentuk nasehat maupun kenaikan gaji setiap tahunnya. Kepala sekolah meningkatkan kemampuan manajerialnya dengan cara banyak belajar melalui membaca, informasi internet, mengikuti pelatihan manajerial. Untuk mengatasi suatu masalah, kepala sekolah mengadakan rapat yang melibatkan para guru dan pegawai dengan memperhatikan analisis SWOT yang keputusan akhirnya ditentukan oleh kepala sekolah, di mana dalam rapat juga disampaikan visi dan misi sekolah serta target yang akan dicapai. Kadang-kadang kepala sekolah juga berbagi tugas dengan wakil kepala sekolah dan masing-masing koordinator bidang studi. Kepala sekolah menanamkan nilai-nilai keislaman di sekolah dengan cara memperdengarkan bacaan Quran dan mewajibkan menghafal 
hadis serta pelaksanaan sholat zhuhur dan ashar berjamaah dan kegiatan kultum di masjid di bawah bimbingan guru. Kepala sekolah juga turut andil dalam pencapaian berbagai prestasi oleh para siswa, baik dengan pemberian izin, motivasi maupun fasilitas yang mendukung para siswa.

4.2 Pelaksanaan Supervisi Akademik Kepala Sekolah SMP Muhammadiyah 1 Medan

\begin{tabular}{|c|l|l|c|}
\hline NO & Nama Guru & $\begin{array}{c}\text { Mata } \\
\text { Pelajaran }\end{array}$ & $\begin{array}{c}\text { Nilai } \\
\text { PKG }\end{array}$ \\
\hline 1 & $\begin{array}{l}\text { Ali Khoir } \\
\text { Hrp }\end{array}$ & IPA & 71,43 \\
\hline 2 & $\begin{array}{l}\text { Ade } \\
\text { Habibah } \\
\text { Siregar }\end{array}$ & IPS & 100 \\
\hline 3 & $\begin{array}{l}\text { Salfius } \\
\text { Budi } \\
\text { Maizan }\end{array}$ & Penjaskes & 80,36 \\
\hline 4 & $\begin{array}{l}\text { Syarifuddin } \\
\text { Aahasa }\end{array}$ & 94,64 \\
\hline 5 & $\begin{array}{l}\text { Lukman } \\
\text { Hendry }\end{array}$ & Matematika & 100 \\
\hline 6 & $\begin{array}{l}\text { Dahlia } \\
\text { Hanum }\end{array}$ & TIK & 100 \\
\hline 7 & Khairunnisa & $\begin{array}{l}\text { Bahasa } \\
\text { Inggris }\end{array}$ & 94,65 \\
\hline 8 & Suharti & $\begin{array}{l}\text { Bahasa } \\
\text { Indonesia }\end{array}$ & 92,86 \\
\hline 9 & Siti Zahrah & PPKN & 100 \\
\hline 10 & $\begin{array}{l}\text { Syahraini } \\
\text { Tambunan }\end{array}$ & $\begin{array}{l}\text { Agama } \\
\text { Islam }\end{array}$ & 82,14 \\
\hline
\end{tabular}

\begin{tabular}{|c|l|l|r|}
11 & $\begin{array}{l}\text { Saidom } \\
\text { Batubara }\end{array}$ & $\begin{array}{l}\text { Quran } \\
\text { Hadis }\end{array}$ & 100 \\
\hline 12 & Devi Puspa & Quran & 100 \\
\hline 13 & Rasmida & Fikih & 100 \\
\hline 14 & Rata-Rata & & 93,54 \\
\hline
\end{tabular}

Penjelasan mengenai PKG para guru yang terdapat di dalam tabel diuraikan sebagai berikut:

Kemampuan Guru bidang studi IPA, Ali Khair Harahap untuk mengenal karakteristik peserta didik, menguasai teori belajar dan prinsip-prinsip pembelajaran yang mendidik, melaksanakan kegiatan pembelajaran yang mendidik, memahami dan mengembangkan potensi, berkomunikasi dengan peserta didik, menilai dan mengevaluasi, bertindak sesuai dengan norma agama, hukum, sosial dan kebudayaan nasional Indonesia, menunjukkan pribadi dewasa dan teladan, etos kerja, tanggung jawab yang tinggi, dan rasa bangga menjadi guru, bersikap inklusif, bertindak objektif, serta tidak diskriminatif berada pada tingkatan di bawah maksimal, sedangkan kemampuan mengembangkan kurikulum dan mengembangkan keprofesian melalui tindakan reflektif lebih rendah lagi. 
Adapun, kinerja guru tersebut dalam mengajar berdasarkan skala Likert dapat dikatakan baik, namun apabila dibandingkan dengan PKG rata-rata keseluruhan guru, nilai PKG guru tersebut masih lebih rendah. Walaupun dikatakan kinerjanya baik, namun menurut hemat penulis, guru tersebut harus berusaha lebih keras lagi untukmemperbaiki kinerja mengajarnya di kelas karena tidak ada satu kompetensi pun, bahkan kompetensi terpenting yang berkaitan dengan profesionalitas guru, yaitu seluruh kompetensiyang berkaitan dengan kegiatan mendidik guru, juga tidak ada yang mencapai tingkat maksimal.

Kemampuan guru bidang studi Penjaskes, Salfius Budi Maizan,untuk melakukan pembelajaran yang mendidik, menilai dan mengevaluasi, bertindak sesuai dengan norma agama, hukum, sosial dan kebudayaan nasional Indonesia, serta menguasai materi, struktur konsep dan pola pikir keilmuan yang mendukung mata pelajaran yang diampu,berada pada tingkatan maksimal, sedangkan mengenal karakteristik peserta didik, menguasai teori belajar dan prinsip-prinsip pembelajaran yang mendidik, mengembangkan kurikulum, memahami dan mengembangkan potensi, berkomunikasi dengan peserta didik, menunjukkan pribadi dewasa dan teladan, etos kerja, tanggung jawab yang tinggi, dan rasa bangga menjadi guru, bersikap inklusif, bertindak objektif, serta tidak diskriminatif, berkomunikasi dengan sesama guru, tenaga pendidikan, orang tua peserta didik dan masyarakat, berada pada tingkatan di bawahnya, dan yang terakhir, kemampuan mengembangkan keprofesian melalui tindakan reflektif lebih rendah lagi. Adapun, kinerja guru tersebut dalam mengajar berdasarkan skala Likert dapat dikatakan baik, namun apabila dibandingkan dengan nilai PKG rata-rata keseluruhan guru, nilai PKG guru tersebut masih rendah. Menurut hemat penulis, kompetensi guru tersebut yang berkaitan dengan profesionalitasnya yaitu kemampuan mengajarnya sebagian sudah baik dan sebagian lagi masih kurang, terutama pada aspek pengembangan pembelajaran, pengenalan karakter anak didik, dan sikap yang ditunjukkan oleh guru tersebut.

Kemampuan guru bidang studi bahasa arab, Syarifuddin, untuk mengenal karakteristik peserta didik, menguasai teori belajar dan prinsip-prinsip pembelajaran yang mendidik, mengembangkan kurikulum, kegiatan 
pembelajaran yang mendidik, komunikasi dengan peserta didik, penilaian dan evaluasi, menunjukkan pribadi dewasa dan teladan, etos kerja, tanggung jawab yang tnggi, dan rasa bangga menjadi guru, bersikap inklusif, bertindak objektif, serta tidak diskriminatif, komunikasi dengan sesama guru, tenaga pendidikan, orang tua peserta didik dan masyarakat, penguasaan materi, struktur konsep dan pola pikir keilmuan yang mendukung mata pelajaran yang diampu berada pada tingkatan maksimal, sedangkan kemampuan memahami dan mengembangkan potensi, bertindak sesuai dengan norma agama, hukum, sosial dan kebudayaan nasional indonesia, mengembangkan keprofesian melalui tindakan reflektif, berada pada tingkatan di bawahnya. Adapun, kinerja guru tersebut dalam mengajar berdasarkan skala Likert dapat dikatakan amat baik, demikian juga apabila dibandingkan dengan nilai rata-rata PKG keseluruhan guru, nilai PKG guru tersebut masih lebih baik. Menurut hemat penulis, sebagian besar kompetensi guru tersebut telah terpenuhi dengan baik, terutama pada kompetensi pengajarannya, hanya sebagian kecil saja yang masih kurang yangtidak terkait langsung terhadap pengajaran guru di kelas.
Kemampuan guru bidang studi Bahasa Inggris, Khairunnisa, untuk mengenal karakteristik peserta didik, melaksanakan kegiatan pembelajaran yang mendidik, memahami dan mengembangkan potensi, komunikasi dengan peserta didik, menilai dan mengevaluasi, bertindak sesuai dengan norma agama, hukum, sosial dan kebudayaan nasional Indonesia, menunjukkan pribadi dewasa dan teladan, etos kerja, tanggung jawab yang tinggi, dan rasa bangga menjadi guru telah berada pada tingkatan maksimal, sedangkan kemampuan menguasai teori belajar dan prinsip-prinsip pembelajaran yang mendidik, bersikap inklusif, bertindak objektif, serta tidak diskriminatif, mengembangkan keprofesian melalui tindakan reflektif berada pada tingkatan di bawahnya,. Adapun, kinerja guru tersebut dalam mengajar berdasarkan skala Likert dapat dikatakan amat baik, demikian juga nilai PKG guru tersebut apabila diandingkan dengan nilai rata-rata PKG keseluruhan guru juga masih lebih baik. Menurut hemat penulis, sebagian besar kompetensi guru tersebut telah terpenuhi dengan baik, namun masih ada juga kompetensi lainnya yang juga penting untuk diperbaiki, terutama 
kompetensi pengajaran guru seperti
menguasai teori dan prinsip-prinsip
mendidiknya.
Kemampuan guru bidang studi

Bahasa Indonesia, Suharti, untuk mengenal karakteristik peserta didik, menguasai teori belajar dan prinsipprinsip pembelajaran yang mendidik, mengembangkan kurikulum melaksanakan kegiatan pembelajaran yang mendidik, memahami dan mengembangkan potensi berkomunikasi dengan peserta didik, menilai dan mengevaluasi, bertindak sesuai dengan norma agama, hukum, sosial dan kebudayaan nasional Indonesia, menunjukkan pribadi dewasa dan teladan, etos kerja, tanggung jawab yang tinggi, dan rasa bangga menjadi guru, bersikap inklusif, bertindak objektif, serta tidak diskriminatif, berkomunikasi dengan sesama guru, tenaga pendidikan, orang tua peserta didik dan masyarakat, menguasai materi, struktur konsep dan pola pikir keilmuan yang mendukung mata pelajaran yang diampu, mengembangkan keprofesian melalui tindakan reflektif berada pada tingkatan maksimal, sedangkan kemampuan berkomunikasi dengan sesama guru, tenaga pendidikan, orang tua peserta didik dan masyarakat, masih berada di bawah tingkatan maksimal, demikian juga kemampuan mengembangkan keprofesian melalui tindakan reflektif, jauh berada di bawah tingkatan maksimal. Adapun kinerja guru tersebut dalam mengajar berdasarkan skala Likert dapat dikatakan baik, namun nilai PKG guru tersebut apabila dibandingkan dengan nilai rata-rata $\mathrm{PKG}$ keseluruhan guru masih rendah. Menurut hemat penulis, sebagian besar kompetensi guru tersebut telah terpenuhi dengan baik, guru tersebut hanya perlu membenahi kemampuan berkomunikasi dengan orang lain dan merefleksi diri.

Kemampuan guru bidang studi Agama Islam, Syahraini Tambunan untuk menilai dan mengevaluasi, bertindak sesuai dengan norma agama, hukum, sosial dan kebudayaan nasional Indonesia, bersikap inklusif, bertindak objektif, serta tidak diskriminatif, penguasaan materi, struktur konsep dan pola pikir keilmuan yang mendukung mata pelajaran yang diampu, berada pada tingkatan maksimal, sedangkan kemampuan guru tersebut dalam mengenal karakteristik peserta didik, menguasai teori belajar dan prinsip-prinsip pembelajaran yang mendidik, mengembangkan kurikulum, melaksanakan kegiatan pembelajaran yang mendidik, memahami 
dan mengembangkan potensi, berkomunikasi dengan peserta didik berada pada tingkatan di bawah maksimal. Adapun, kinerja guru tersebut dalam mengajar berdasarkan skala Likert dapat dikatakan amat baik, namun apabila dibandingkan dengan nilai PKG rata-rata keseluruhan guru, nilai PKG guru tersebut masih lebih rendah. Menurut hemat penulis, kompetensi guru tersebut yang berkaitan dengan profesionalitasnya yaitu kemampuan mengajarnya sebagian sudah baik dan sebagian lagi masih kurang, sehingga perlu dibenahi, yaitu pada pengembangan kegiatan mengajar dan pengenalan karakter peserta didik.

Guru bidang studi IPS, Ade Habibah Siregar, Guru TIK, Dahlia Hanum, Guru PPKN, Siti Zahrah, Guru Quran, Saidom Batubara, Guru Quran Hadis, Devi Puspa, Guru Fikih, Rasmida memperoleh nilai PKG 100. Hal itu menunjukkan bahwa guru tersebut telah mengajar dengan sebaik-baiknya karena telah memenuhi seluruh kompetensi dengan angka maksimal. Apabila dikonversikan dengan skala Likert, maka dapat dikatakan bahwa kinerja mengajar guru tersebut amat baik.

\section{E. Kesimpulan dan Saran}

\subsection{Kesimpulan}

Berdasarkan hasil penelitian dan pembahasan dapat disimpulkan sebagai berikut :

Kepemimpinan yang dijalankan oleh kepala sekolah SMP Muhammadiyah 1 Medan lebih banyak bertumpu pada kepribadian pemimpin (traits), hal itu terlihat pada banyaknya upaya yang dilakukan oleh kepala sekolah dalam rangka memajukan sekolah, menjalin hubungan yang bersahabat dengan guru, menasehati guru, mendengarkan pendapat guru, bertindak sebagai penganalisis dan penentu dalam pengambilan keputusan, menambah pengetahuan kepemimpinan dengan belajar melalui berbagai media, memotivasi guru untuk meningkatkan kinerjanya dan memiliki andil dalam pencapaian prestasi dengan memberikan perhatian, motivasi dan memfasilitasi peserta didik yang akan mengikuti perlombaan. Adapun kepemimpinan situasional kepala sekolah terlihat pada pelimpahan tugas kepada wakil kepala sekolah, koordinator-koordinator bidang studi, bimbingan konseling, psikolog, bahkan guru kelas.

Pelaksanaan supervisi akademik kepala sekolah sudah efektif, hal itu 
terlihat dari nilai PKG yang diperoleh oleh para guru bidang studi yang hampir semua berada pada tingkatan amat baik, bahkan hampir sempurna, hanya dua orang saja yang masih berpredikat baik. Demikian juga dengan nilai rata-rata keseluruhan guru bidang studi berada pada tingkatan amat baik. Apabila dibandingkan nilai masing-masing guru dengan rata-rata pun, sebagian besar masih tetap amat baik.

Penyelenggaraan pendidikan di SMP Muhammadiyah 1 Medan berada di bawah pengawasan Majelis Pendidikan Dasar dan Menengah (Dikdasmen) Muhammadiyah Pimpinan Cabang Medan Kota. Secara hirarki, guru bidang studi bertanggung jawab terhadap koordinator bidang studi, dan koordinator bidang studi bertanggung jawab terhadap kepala sekolah, dan kepala sekolah bertanggung jawab terhadap Dikdasmen. Menurut hemat penulis, dengan sistem pengawasan ini, ditambah dengan penerapan kurikulum K-13 pada kelas VII dan VIII, penyelenggaraan proses pendidikan dapat dilakukan secara profesional dan optimal. Penulis menambahkan, selain itu, sebagai sekolah Islam, yang menekankan pada mata pelajaran agama, apabila digabungkan antara yang akademik dan ekstrakurikuler, maka porsinya lebih banyak dari mata pelajaran lainnya. Halhal tersebut merupakan faktor-faktor yang menjadi kunci keberhasilan SMP Muhammadiyah 1 Medan dalam meraih berbagai prestasi.

\subsection{Saran}

Adapun saran-saran yang dikemukakan oleh penulis bagi kepala sekolah adalah sebagai berikut :

Upaya yang dilakukan oleh kepala sekolah untuk memajukan sekolah baik yang bersifat eksternal maupun yang bersifat internal sudah baik, tapi sedikit tambahan, sebaiknya kepala sekolah menjalin hubungan dengan perusahaan atau instansi baik instansi negeri maupun swasta untuk menjadi mitra yang bisa menampung lulusan sekolah, bahkan menjadi donatur sekolah. Begitu juga dengan hubungan terhadap para orang tua peserta didik, tidak hanya dilakukan ketika peserta didik bermasalah saja, tapi sebaiknya sering, sehingga orang tua dapat mengetahui bagaimana perkembangan akademik ataupun akhlak peserta didik di sekolah.

Pelaksanaan supervisi akademik kepala sekolah sudah efektif sehingga menghasilkan kinerja guru yang amat baik, tapi belum seluruhnya sempurna. 
Kepala sekolah harus lebih meningkatkan pemberdayaan guru melalui kegiatan supervisi akademik, sehingga seluruh nilai para guru bisa mencapai sempurna.

Kepala sekolah agar dapat melaksanakan kurikulum K-13, tidak hanya pada kelas VII dan kelas VIII saja, tapi seluruh kelas. Demikian juga dengan pemanfaatan laboratorium bahasa dan IPA agar ditingkatkan pemanfaatannya seefektif mungkin sebagaimana yang telah diterapkan pada laboratorium komputer. Jika memungkinkan, kepala sekolah bisa menambahkan internet di sekolah untuk meningkatkan pengetahuan dan pembelajaran peserta didik, tentunya penggunaannya harus diawasi oleh guru, agar tidak disalahgunakan oleh peserta didik kepada hal-hal yang merusak jiwa dan akhlak peserta didik.

\section{DAFTAR PUSTAKA}

A. Ametembun, N. Kepemimpinan dalam Perubahan Pendidikan ; Suatu Pendekatan Sistem. Bandung : Fakultas Ilmu Pendidikan IKIP, 1981, cetakan ke-2

Arikunto, Suharsimi. Dasar-Dasar Supervisi. Jakarta : Rineka Cipta, cetakan ke-1, 2004

Bahri, Syaiful. Optimalisasi Kinerja Kepala Sekolah. Jakarta : Gibon Books, cetakan ke-1, 2010
Grace, Gerald. School Leadership: Beyond Education Management An Essay in Policy Scholarship. London: The Falmer Press, 1995

Hasbullah, Kapita Selekta Pendidikan Islam di Indonesia. Jakarta : Raja Grafindo Persada, Edisi ke-1, cetakan ke-1, 1996

Hersey, Paul et.al. Management of Organizational Behavior ; Leading Human Resources. India : Prentice Hall of India Private Limited, Edisi ke-8, 2002

James M. Aseltine. et.al, Supervision for Learning ; a Performance Based Approach to Teacher Development and School Improvement. Virginia : Association for Supervision and Development, 2006

Lubis, Arbiyah. Pemikiran Muhammadiyah dan Muhammad Abduh ; Suatu Studi Perbandingan. Jakarta : Bulan Bintang, cetakan ke-1, 1993

Mukhtar, et.al, Sekolah Berprestasi. Jakarta : Nimas Multimah, cetakan ke-3, 2005

Nasional, Pusat Bahasa Departemen Pendidikan Kamus Besar Bahasa Indonesia. Jakarta : Balai Pustaka, Edisi III, cetakan ke-4, 2007 
Purwanto, Ngalim. Administrasi dan Supervisi Pendidikan. Bandung : Remaja Rosda Karya, cetakan ke-15, 2005

R. Terry, George. Principles of Management. Illinois : Richard D.Irwin Inc, Edisi VII, 1977

Rivai, Veithzal dan Sylviana Murni. Education Management ; Analisis Teori dan Praktik. Jakarta : Rajawali Pers, Edisi I, cetakan ke-2, 2010

Siddik, Dja'far. Pendidikan Muhammadiyah ; Perspektif Ilmu Pendidikan. Bandung : Citapustaka Media, cetakan ke-1, 2007

Tohirin, Metode Penelitian Kualitatif dalam Pendidikan dan Bimbingan dan Konseling ; Pendekatan Praktis untuk Peneliti Pemula dan Dilengkapi dengan Contoh Transkrip Hasil Wawancara serta Model Penyajian Data. Jakarta : Rajawali Pers, Edisi I, cetakan ke-3, 2013

Weihrich, Heinz dan Harold Koontz, Management; a Global Perspective. Singapore : The McGraw-Hill Companies, Edisi XI, 2005

Wiles, Kimball. Supervision for Better School.Englewood Cliffs, New Jersey : Prentice-Hall Inc, Edisi III, 1967

Winaryati, Eny. Evaluasi Supervisi Pembelajaran ; Dilengkapi Instrumen
Pembelajaran.Yogyakarta : Graha Ilmu, cetakan ke-1, 2014

Yukl, Gary. Leadership in Organizations.New York : Pearson Prentice Hall, Edisi VII, 2010 